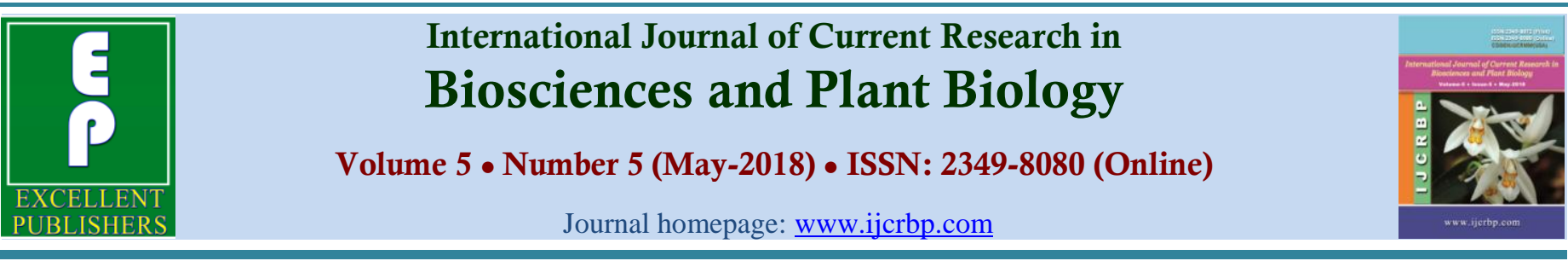

\title{
Exploration of Native Mycorrhiza on Rhizosphere of Gleichenia linearis in Nickel Post-Mining Rehabilitation Area of Sorowako, Indonesia
}

\author{
Muhammad Akhsan Akib1, Kahar Mustari², Tutik Kuswinanti ${ }^{3 *}$ \\ and Syatrianty Andi Syaiful²
}

${ }^{1}$ Graduate School, Hasanuddin University, Makassar, South Sulawesi, 90245, Indonesia; and Department of Agrotechnology, Faculty of Agriculture, Animal Husbandry and Fishery, Muhammadiyah University of Parepare, South Sulawesi, 91131, Indonesia

2Department of Agronomy Faculty of Agriculture, Hasanuddin University, Makassar, South Sulawesi, 90245, Indonesia

${ }^{3}$ Department of Plant Pests and Diseases Faculty of Agriculture, Hasanuddin University, Makassar, South Sulawesi, 90245, Indonesia

${ }^{*}$ Corresponding author.

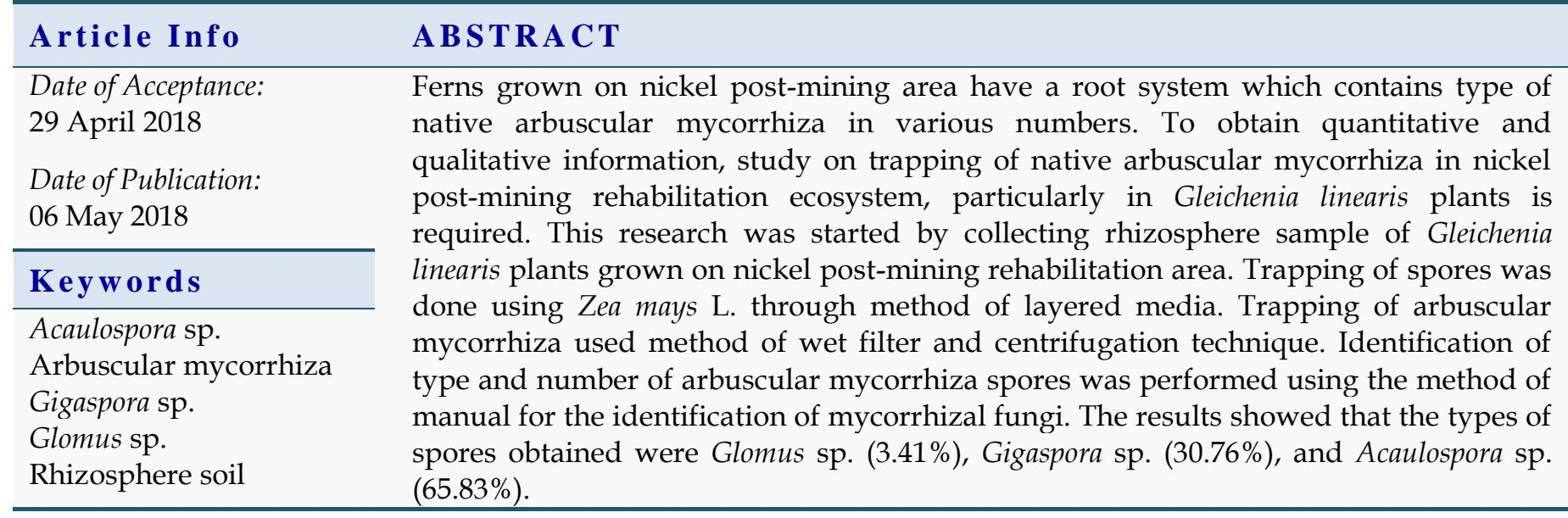

\section{Introduction}

Vale Indonesia is a nickel mining company located in Sorowako, Nuha Sub-District, East Luwu Regency, and South Sulawesi Province.
Contract of work of Vale Indonesia covers an area of 218,528.99 ha which is divided into several areas namely $118,387.45$ ha in Sorowako (South Sulawesi), 63,506.18 ha in Pomalaa (Southeast Sulawesi), and $36,635.36$ ha in 
Bahodopi (Central Sulawesi) (Maruto, 2013; Fachrul, 2013). Of the total area owned in South Sulawesi, total mining area has reached 4,973.1 ha in 2014 and increased to 5,176.1 ha in 2015, while area which has been rehabilitated and reclaimed was 3,975.9 ha in 2014 and 3,985.5 ha in 2015 with the accumulation of the number of trees planted amounted to $1,859,107$ trees (Vale, 2015). By observing the data, it can be seen that the rate of increase in mining area was faster (203 ha) than the rate of rehabilitation activities (9.6 ha).

Increasing rate of rehabilitation activities can be done with the implementation of various technologies. One of technologies that can be applied is the technology of mycorrhizal biological agent. Most of the roots of various plant species form a symbiotic relationship including with type of mycorrhiza. In natural environments, almost 80 to $96 \%$ of plant roots form a mutualism association with mycorrhiza (Sufaati et al., 2011; Prayudyaningsih and Sari, 2016). There are two main types of mycorrhiza commonly found: endomycorrhiza and ectomycorrhiza (Cahyani et al., 2014). One type of endomycorrhiza is the arbuscular mycorrhiza (AM) of which its hyphae grows and develops into the cortex tissue of plant roots (Santoso et al., 2016). In nickel post-mining rehabilitation area, three genus of Arbuscular Mycorrhiza (AM) that dominated the area were found, namely: Glomus sp., Acaulospora sp. and Gigaspora sp. (Setiadi and Setiawan, 2011).

Information considering the type and abundance of AM on Gleichenia linearis plants grown in nickel post-mining rehabilitation areas, especially in Sorowako Village has not been reported; therefore, knowing the type and abundance of AM on rhizosphere of Gleichenia linearis plants as an initial stage in utilizing AM as a biological agent is the purpose of this study. It is expected that the results of this study would obtain pure isolates of native AM from rhizosphere of Gleichenia linearis plant so that further research on the compatibility and effectiveness of AM types in reforestation plants can be carried out to accelerate the management of nickel post-mining rehabilitation.

\section{Materials and methods}

This research was conducted in three stages: sampling of rhizosphere plant in nickel post-mining rehabilitation area of Vale Indonesia in Sorowako, trapping culture through the method of layered media in Nursery Agroplastid Parepare, and direct observation of population abundance of AM spores type of Gigaspora sp., Acaulospora sp. and Glomus sp. in Laboratory of Microbiology of Environment and Forestry Research and Development Institute of Makassar.

\section{Sampling of rhizosphere of plant}

Sampling of rhizosphere on Gleichenia linearis plant was conducted at several nickel post-mining locations where mining activities have been closed and the area has been rehabilitated. The sampling method of rhizosphere plant was done diagonally at 5 points. Each sample was taken as much as $1,500 \mathrm{~g}$ around the roots at a distance of $10-25 \mathrm{~cm}$ from the base of the plant stem with a depth of 0-25 $\mathrm{cm}$ and further put into the sample bag, root sampling was done by cutting the end part of young root.

\section{Trapping culture}

Trapping culture was done to obtain spores with high viability. The host plant used was corn (Zea mays). The sterilized host plant seeds were planted in small pots (10 cm diameter) contained sand which was previously sterilized, as well as the rhizosphere sample of plant from the post-mining area. In each pot, sandy soil of $\pm 250 \mathrm{~g}$ was put at the bottom layer, rhizosphere sample of $\pm 150 \mathrm{~g}$ from the field was further added and sandy soil of $50 \mathrm{~g}$ was placed at the top part. Plants were kept at the screen house until the age of 3 months. Maintenance was done by watering the plants every day and liquid organic fertilizer with a concentration of $3 \mathrm{~g} .1^{-1}$ was given every 2 days for 1 month. After 3 months, the sand medium from each pot was filtered to isolate AM spores. 


\section{Isolation and abundance of arbuscular mycorrhizal type}

Status of abundance and type of AM was determined by weighing soil sample of 100 grams. The sample was then put in $1000 \mathrm{ml}$ beaker glass and water was added until the volume reached $1 \mathrm{~L}$. The soil was stirred for \pm 5 minutes until it was homogeneous and the suspension was left for \pm 3 minutes until the large particles settled. The supernatant liquid was poured into the stratified filter at the size of 40 mesh, 50 mesh, and 324 mesh (this procedure was repeated 2-3 times). The residue of each filter was rinsed in running water to ensure that all small particles were carried away. The particles left on the filter of 325 mesh and 50 mesh were centrifuged at 2,500 rpm for 5 minutes. Half of supernatant was removed and $50 \%$ glucose solution was added then centrifuged at 1,200 rpm for 2 minutes. The supernatant layer which had been added glucose solution was poured through a 325 mesh filter then washed using flowing water until the glucose solution was fully removed. The filter results were poured into a Petri dish, then calculated and identified under a binocular microscope. The microscopic characteristics of the spores found were then matched with the identification guidelines used by INVAM (2017) to determine the type of AM found.

\section{Data analysis}

The data of the calculation of population abundance of AM spores type of Gigaspora sp., Acalouspora sp. and Glomus sp. conducted in 5 replications of rhizosphere sample of Gleichenia linearis plant are presented in the form of a pie chart.

\section{Results and discussion}

\section{Gleichenia linearis plants}

Another name for Gleichenia linearis is Dicranopteris linearis. This species is included in family Gleicheniaceae with local name of pakiskawat and sampilpil (Fig. 1). It is a perennial creeping fern which often forms a dense 'sheet' and included as an important weed on plantations.

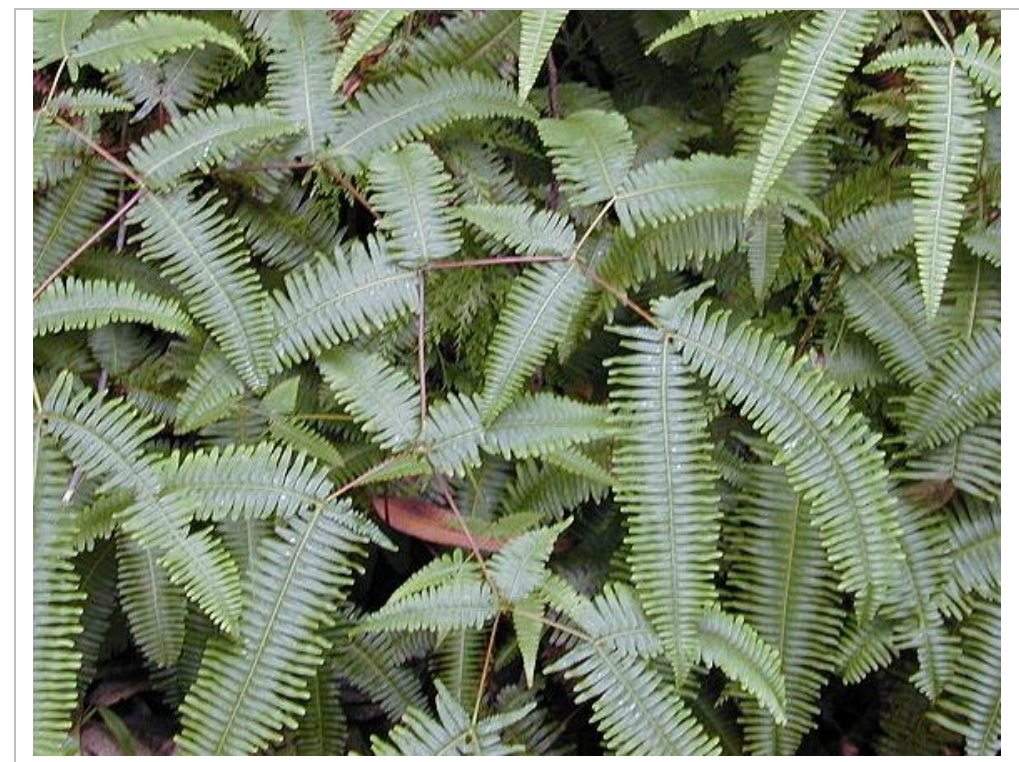

(A)

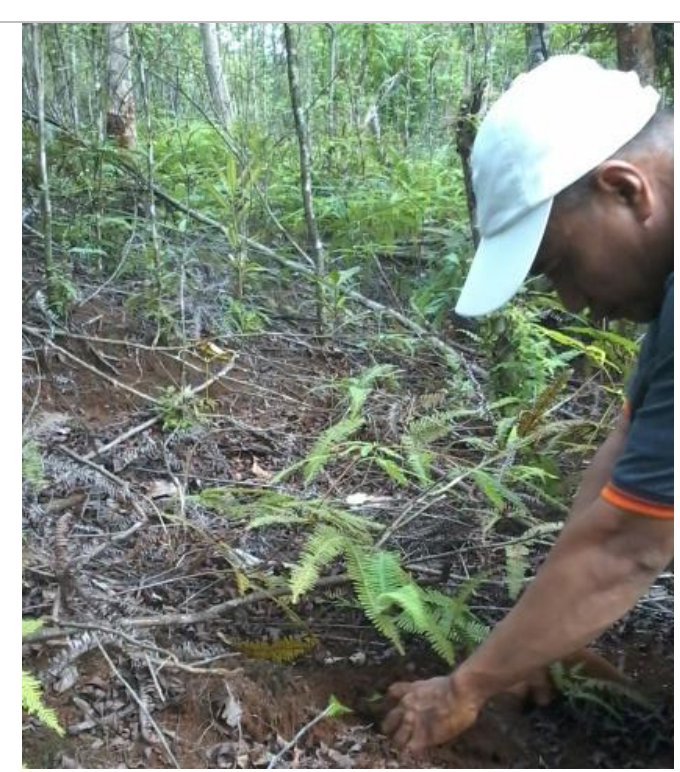

(B)

Fig. 1: (A) Gleichenia linearis; (B) Collection of rhizosphere soil.

Gleichenia linearisis a type of large fern, its habitat is shaded and humid cliffs ranging from $30 \mathrm{~m}$ to 2,800 $\mathrm{m}$ above sea level, this plant can be found in almost all tropical and subtropical regions of Asia and the Pacific, sometimes in a dense forest, open areas of the forest, open forest area, secondary 
forest exposed to sunlight, ravine, slopes and riverside (Fenny, 2010).

Gleichenia linearis plant is very useful since it is able to fertilize the soil, absorb toxins around the area it grows. However, Gleichenia linearis is known as an invasive plant in some places because it dominates the soil surface with its crawling rhizome roots, either climbing or hanging, thus hamper the growth of other plants (Susanti et al., 2014).

\section{Abundance of arbuscular mycorrhizal spores}

At succession stage, the formation of a vegetation consists of regular stages starting with stage of which a new plant species enters to an area to grow, called the invasion stage, the plant then adapts and further lives together with other migrant plants, called the aggregation stage, continues with the stage of competition and when a balance is reached, it is called as the stabilization stage (Susilawatid and Maryati, 2012).

The growth and development of well-adapted and well-developed tree, shrub, and fern vegetation provide sufficient habitat and energy supply for the growth and development of AM spores. Sundari et al. (2011) stated that the presence of AM in an area is strongly influenced by environmental factors. Result of re-vegetation for 12 years showed that all of the soil physical variables (texture, volume weight, total porosity, moisture content, and penetration resistance) and soil chemical variables (pH, organic carbon, nutrients, exchangeable cations, and cation exchange capacity) have increased to a better level (Hermawan, 2011) for the formation of rhizosphere. Gleichenia linearis plants grown on nickel post-mining rehabilitation area were found to have the abundance of AM spores of Gigaspora sp., Acalouspora sp., and Glomus sp. (Fig. 2).

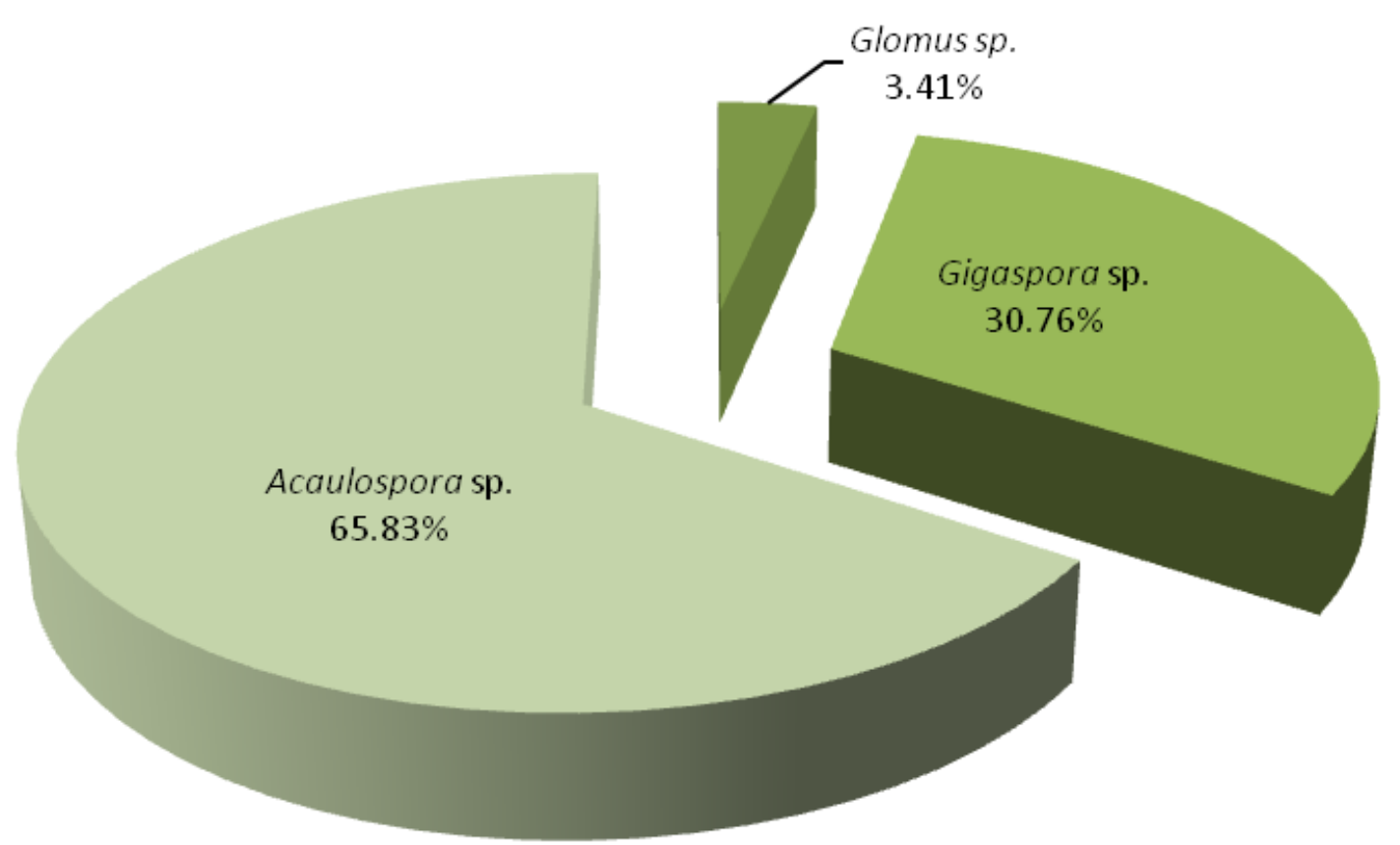

Fig. 2: Percentage of Population Abundance of AM Spores on Rhizosphere of Gleichenia linearis plant in nickel post-mining rehabilitation area.

The rhizosphere is an excellent habitat for microbial growth because the plant roots provide various organic matters that generally stimulate the growth of microbes. Organic matter released by the roots can be in the form of root exudate (Fajarwati, 2007;
Wihardjaka, 2010), root secretion and lysates (Sari, 2015), mucigel (Takehisa et al., 2012). Several factors affecting the rhizosphere effect are soil type, soil moisture, soil $\mathrm{pH}$, soil temperature, plant age, and crop conditions (Budiyanto, 2015). The 
rhizosphere is divided into 2 main zones: Endorhizosphere: stele, epidermis, cortex, endodermis and root cap, and Ectorhizosphere: the area around the roots, from the soil contact zones to root surfaces influenced by root exudates (Ali and Rante, 2011; Budiyanto, 2015). Bais et al. (2006) stated that the rhizosphere covers the space around the plant roots at a distance of several millimeters in which biological complexes and ecological processes exist, as well as mediates the biological interactions in the soil (Narula et al., 2008; Huang et al., 2014).
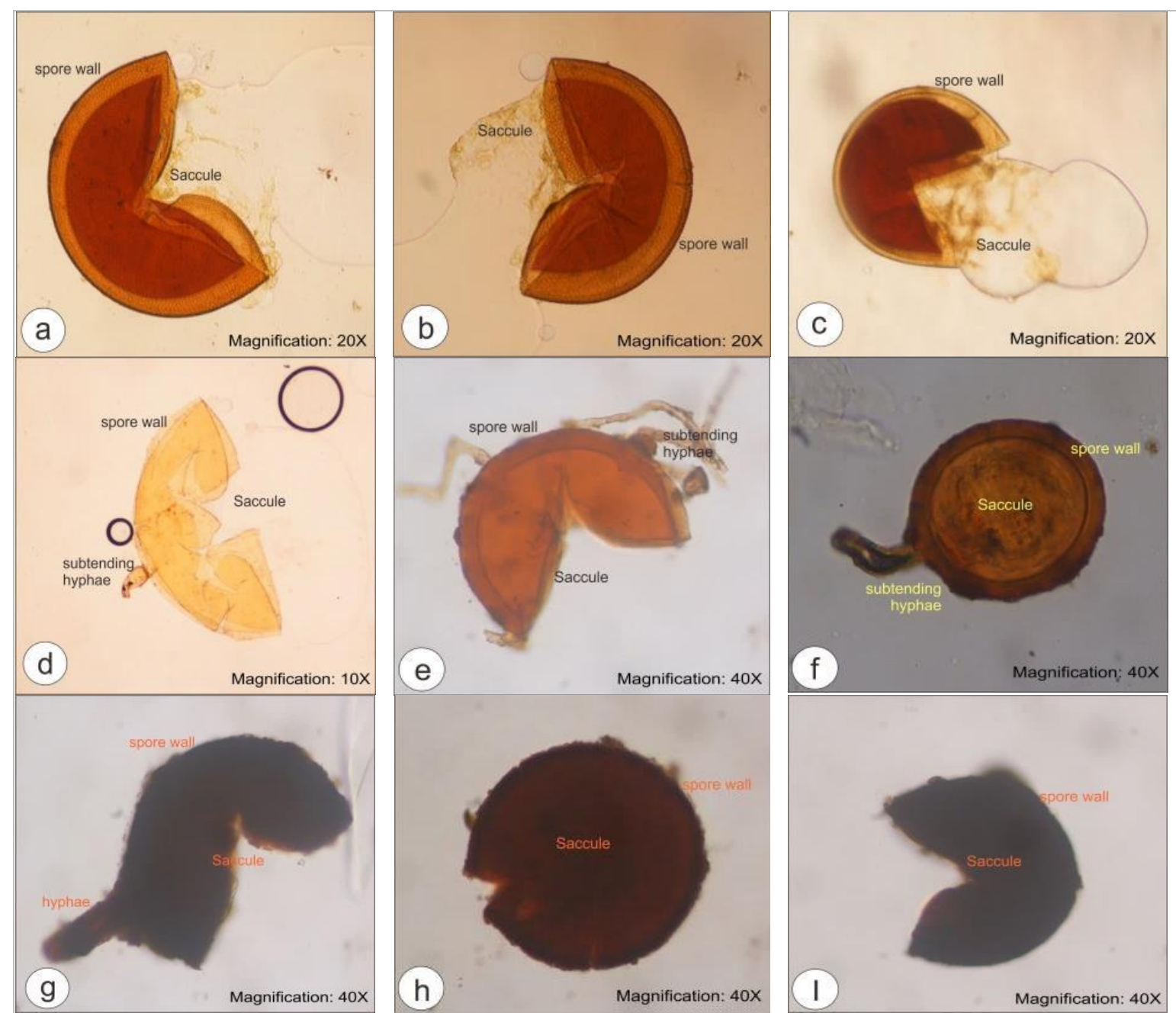

Fig. 3: Arbuscular mycorrhiza on rhizosphere of Gleichenia linearis plant in nickel post-mining rehabilitation area: Acaulospora sp. (a - c), Gigaspora sp. (d - f) and Glomus sp. (g - i).

Delvian (2005) summarized several opinions of researchers on AM growth and development. It is stated that germination of AM spore can be divided into 4 phases, namely hydration, activation, growth of germ tube emergence and hyphal growth. In the first phase, water enters the spores so that the components in the spores are hydrated. After the hydration phase, some or all organelles and macromolecules become intact, ribonucleic acid and enzyme become active thus resulting in increased metabolic activity. Two to 10 days after the hydration, spores become active and the germ tube begins to grow which is followed by the growth of hyphae. The first infection is influenced by: (1) germination of spores or other fungal propagules; (2) the growth of hyphae in soil, in some AMs, the growth of germ tube of germinated spores may be 
influenced by root exudates, soil fertility and groundwater availability, and (3) the entry point on plant roots. Each of these stages can be a limiting stage in the AM formation process. Secondary infections are strongly influenced by physiology of host plant since most of the energy used for the spread of hyphae is obtained from photosynthesis product which is translocated from plants to fungi, either through arbuscules or internal hyphae.

\section{Isolation and identification of native arbuscular mycorrhiza spores}

The spore type isolated from the rhizosphere of Gleichenia linearis plant has different shape and color. Spores are then grouped by shape and color thus obtaining three types of AM spores, namely Gigaspora sp., Acaulospora sp. and Glomus sp. (Fig. 3).

Microscopically, each type of spore obtained is found to have distinctive characteristics, such as type of Acaulospora spore has thick walls and ornaments, type of Gigaspora spore has bulbous suspensor at the base of its hyphae without germination layer, and type of Glomus spore has subtending hyphae (INVAM, 2017).

\section{Conclusion}

The spore types of native arbuscular mycorrhiza found in rhizosphere of Gleichenia linearis plants were found to be $3.41 \%$ of Glomus sp. Type, $30.76 \%$ of Gigaspora sp. type and $65.83 \%$ of Acalouspora sp. type.

\section{Conflict of interest statement}

Authors declare that they have no conflict of interest.

\section{Acknowledgement}

Special gratitude is given to Vale Indonesia, Environment and Forestry Research and Development Institute of Makassar.

\section{References}

Ali, A., Rante, H., 2011. Karakterisasi Mikrobia Rizosfer asal Tanaman Ginseng Jawa (Talinum triangulare) berdasarkan Gen Ribosomal 16S rRNA dan 18S. J. Biol. Papua. 3, 74-81.

Bais, H. P., Weir, T. L., Perry, L. G., Gilroy, S., Vivanco, J.M., 2006. The role of root exudates in rhizosphere interactions with plants and other organisms. Annu. Rev. Plant Biol. 57, 233-266.

Budiyanto, G., 2015. Interaksi Biologi Nitrogen Dalam Tanah. Makalah Kuliah Umum Program Studi Agroteknologi Fakultas Pertanian Universitas Muhammadiyah Yogyakarta.

Cahyani, N. K. M. D., S. Nurhatikadan A. Muhibuddin. 2014. Eksplorasi Mikoriza Vesikular Arbuskular (MVA) Indigenous pada Tanah Aluvial di Kabupaten Pamekasan Madura. J. Sains SeniPomits. 3, 2337-3520.

Delvian, 2005. Respon Pertumbuhan Dan Perkembangan Cendawan Mikoriza Arbuskula Dan TanamanTerhadap Salinitas Tanah. www.library.usu.ac.id

Fachrul, R. M., 2013. PT. Vale Indonesia Tbk "Migrasi Data Menggunakan Pcmover Enterprise" PoliteknikNegeri Ujung Pandang Makassar.

Fajarwati, I., 2007. Organic Acid Secretion On AlStressed Rice. Departemen Biologi Fakultas Matematika Dan Ilmu Pengetahuan Alam. Institut Pertanian Bogor.

Fenny, 2010. The Effectiveness test of Paraquat, Glyphosate, and Glufosinate Single and Mixture on Fern Wire ( $G$. linearis) in Rubber Plantation. Skripsi Fakultas Pertanian Universitas Sumatera Utara.

Hermawan, B., 2011. Peningkatan Kualitas Lahan Bekas Tambang melalui Revegetasidan Kesesuaiannya Sebagai Lahan PertanianTanaman Pangan. Prosiding Seminar Nasional Budidaya Pertanian. Bengkulu 7 Juli 2011. Hal: 60-70. ISBN 978-602-19247-0-9.

Huang, X. F., Chaparro, J. M., Reardon, K. F., Zhang, R., Shen, Q., Vivanco, J. M., 2014. Rhizosphere interactions: Root exudates, microbes, and microbial communities. Botany. 92, 267-275. 
INVAM, 2017. International culture collection of (vesicular) arbuscular mycorrhizal fungi. Tersedia:http://invam.caf.wvu.edu/Mycoinfo/Ta xonomy/classification.htm.

Maruto, R., 2013. PT Vale Akan Lepas 13.000 HektareLahan.www.antarasulteng.com. Diakses 8 Maret 2016.

Narula, N., Kothe, E., Behl, R. K., 2009. Role of root exudates in plant-microbe interactions. $\mathrm{J}$. Appl. Bot. Food Qual. 82, 122-130.

Prayudyaningsih, P., Sari, R., 2016. The application of arbuscular mycorrhizal fungi (AMF) and compost to improve the growth of teak seedlings (Tectona grandis Linn. f.) on limestone post-mining soil. J. Penel. Kehut. Wall. 5, 37-46.

Santoso, C. A., Anom, E., Murniaty., 2016. Effectiveness of grant of fertilizer on biological mycorrhizal $\mathrm{P}$ absorption, growth and production of sweet corn (Zea mays Saccharata Sturt) in peatlands. JOM FAPERTA. 3, 1-9.

Sari, D. R., 2015. Isolation and identification soil bacteria around plant roots. Bio-Site. 1, 21-27.

Setiadi, Y., Setawan, A., 2011. Study of arbuscular mycorrhizal fungi status at rehabilitation postnickel mining area (Case study at PT INCO Tbk. Sorowako, South Sulawesi). J. Silvikult. Trop. 3, 88-95.

Sufaati, S., Suharno., Bone, I. H., 2011. Endomikoriza yang Berasosiasidengan Tanaman Pertanian Non-legum di Lahan Pertanian Daerah Transmigrasi Koya Barat, Kota Jayapura. J. Biol. Papua. 3, 1-8.
Sundari, S., Nurhindayati, T., Trisnawati, I., 2011. Isolasidan Identifikasi Mikoriza Indigenous dari Perakaran Tembakau Sawah (Nicotiana tabacum L.) di Area Persawahan Kabupaten Madura. Fakultasmatematikadan Ilmu Pengetahuan Alam, Institut Teknologi Sepuluh November.

Susanti, A. T. A., Isda, M. N., Fatonah, S., 2014. Potensi Alelopati Ekstrak Daun Gleichenia linearis (Burm.) Underw. Terhadap Perkecambahan Dan Pertumbuhan Anakan Gulma Mikania micrantha (L.) Kunth. JOM FMIPA. 1, 1-7.

Susilawati., Maryati, A., 2012. Identifikasi Mikroba Rhizosfer Tumbuhan Pioner Di Lahan Eks Penambangan Batubara Sebagai Bahan Bioremedias. Balai Pengkajian Teknologi Pertanian Kalimantan Tenga. www.pkpp. ristek.go.id. Diakses 13 September 2016.

Takehisa, H., Sato, Y., Igarashi, M., Abiko, T., Antonio, B. A., Kamatsuki, K., Minami, H., Namiki, N., Inukai, Y., Nakazono, M., Nagamura, Y., 2012. Genome-wide transcriptome dissection of the rice root system: Implications for developmental and physiological functions. Plant J. 69, 126-140.

Vale, 2015. Sustainability Report 2015 PT. Vale Indonesia Tbk, Unwavering Commitment. www.vale.com/indonesia.

Wihardjaka, A., 2010. Emisi Gas Dinitrogen Oksidadari Tanah SawahTadah Hujan yang diberi Jerami Padidan Bahan Penghambat Nitrifikasi. J. Biol. Indon. 6, 211-224.

\section{How to cite this article:}

Akib, M. A., Mustari, K., Kuswinanti, T., Syaiful, S. A., 2018. Exploration of native mycorrhiza on rhizosphere of Gleichenia linearis in nickel post-mining rehabilitation area of Sorowako, Indonesia. Int. J. Curr. Res. Biosci. Plant Biol. 5(5), 30-36. doi: https://doi.org/10.20546/ijcrbp.2018.505.005 